\title{
THE TAPETUM IN SCYLIORHINUS CANICULA
}

\author{
By J. A. C. Nicol \\ The Plymouth Laboratory
}

(Text-figs. I-3)

Elasmobranchs are peculiar in having a chorioidal tapetum which, according to Franz (1905), is occlusible. The tapetum lies in the outer region of the chorioid and contains flat cells, in which there is a reflecting material believed to be guanine. Over much of the eye they are arranged obliquely to the retinal surface, extending outwards to the choriocapillaris like overlapping tiles. A flattened nucleus lies midway along the external surface of each plate. The inner surface of the tapetum is occupied by a single layer of spherical pigment cells possessing processes which may extend outwards over the reflecting plates or cells. These pigment cells contain a dark pigment, presumably melanin. When the pigment cell processes extend all the way to the choriocapillaris and cover the reflecting plates, the retina appears black, the tapetum is occluded and no light is reflected back upon the retina. This description is the one usually presented for the elasmobranch eye (Franz, 1913, I934; Walls, I942, Rochon-Duvigneaud, I958; Nicol, I960).

A pigment cell usually has one process; occasionally, it possesses two processes, supplying two reflecting or tapetal plates. It appears from Franz's accounts that the processes of the pigment cells move outwards and inwards, in contrast to the behaviour of skin melanophores, which have fixed processes in which pigment granules make excursions. The chorioid, internal to the layer of migratory pigment cells, has flattened static pigment cells containing black pigment.

Some special features of the elasmobranch tapetum are these. A stripe ('tapetal stripe, horizontal stripe') across the fundus appears especially bright. The stripe lies slightly above the optic papilla and is usually horizontal, but slightly oblique in Scyliorhinus. In this region the tapetal plates are undulating and tangential to the retinal surface, and the tapetum is exposed, fixed and non-occlusible. Often the ventral region of the eye is black: this, the ventral field, is triangular in shape, the apex extending up to, and sometimes including, the optic papilla (Scyliorhinus, Raja). The pigment cell processes are closely spaced and, together with the reflecting plates, are arranged vertically. In the ventral field the tapetum is permanently black and occluded. Sometimes there is a permanent black band at the top of the fundus, as in Scyliorhinus (see Franz, I93I, 1934). A second type of tapetum 
occurs in Lamna cornubica, in which the tapetal plates are superposed in layers parallel to the surface of the retina. Melanophores and their processes extend through the entire tapetum (Rochon-Duvigneaud, I943). A tapetum lucidum is absent in Laemargus, Myliobatis and Cetorhinus maximus (see Franz, 1934).

It is not obvious from published descriptions what regions of the elasmobranch tapetum are occlusible. The tapetal stripe across the fundus is nonocclusible and permanently bright, the ventral and dorsal fields occluded and permanently black. Presumably, lateral fields and those tapetal areas of the fundus lying between the central tapetal or horizontal stripe and the ventral and dorsal black fields are occlusible.

The present study was undertaken to determine factors and agencies controlling pigment migration in the tapetum, especially direct and indirect influence of light, possibility of diurnal rhythmicity, and existence of neural or endocrine control.

\section{MATERIALS AND METHODS}

Dogfish, Scyliorhinus canicula, were kept in tanks at $15^{\circ} \mathrm{C}$ and were treated in ways to be described. In each test three specimens were used, unless stated otherwise.

Series I. Dogfish were placed in the dark at $17.00 \mathrm{~h}$ (approx.), and they were sacrificed in the dark next day at $06.00, \mathrm{I} 2.00, \mathrm{I} 8.00$ and $24.00 \mathrm{~h}$ ( $\mathrm{I}_{3}$, I9, 25 and $3 \mathrm{I} \mathrm{h}$ in the dark, respectively).

Series 2. Dogfish were placed in the dark at $17.00 \mathrm{~h}$ (approx.), light came on at $06.00 \mathrm{hr}$ next day, and fish were sacrificed in the light at $12.00, \mathrm{I} 8.00$, $24.00 \mathrm{~h}$ that day, and $06.00 \mathrm{~h}$ next day $(6, \mathrm{I} 2, \mathrm{I} 8$ and $24 \mathrm{~h}$ in the light, respectively). Lights were two roo $\mathrm{W}$ bulbs.

Series 3. Dogfish were placed in the dark at $17.00 \mathrm{~h}$ (approx.). Fish were killed next morning, in the dark, at $09.30 \mathrm{~h}$, the eyes were excised and the lenses removed. Eyes were then placed in Nicholls's selachian Ringer at $15^{\circ} \mathrm{C}$, and kept in darkness or light for periods of $\mathrm{I}$ and $2 \mathrm{~h}$. Lights were two $100 \mathrm{~W}$ bulbs.

Series 4. Dogfish were placed in a tank which was continuously illuminated from below by two $75 \mathrm{~W}$ bulbs; other light was excluded. One fish was killed at each of these periods: $4,9,18$ and 38 days.

Series 5. Two dogfish, in the dark overnight, were killed in the morning. Eyes were removed, opened, and placed in Ringer; one eye from each fish was kept in the dark for an hour, the other exposed to daylight for an hour, when the two eyes were compared.

Series 6. Two dogfish were placed in the dark for $30 \mathrm{~min}$, then subjected to bright light (two $500 \mathrm{~W}$ photofloods) for $2 \frac{1}{2} \mathrm{~h}$. Eyes of these fish were dissected out in the light and examined.

Eyes of dogfish which were killed in the dark were dissected out under a 
dim red light. When these eyes were preserved, they were placed in fixative in the dark. Dogfish exposed to light were killed in the light, and their eyes dissected out and preserved in the light. Eyes were fixed in Zenker's fluid; the fixed eyes were kept in the dark or light for an hour or so according to their previous history.

For microscopic examination eyes were embedded in polyester wax and sectioned horizontally at го $\mu$. To estimate the degree of pigment dispersion, an index of I to 5 was used: I, processes fully retracted; 2, one-quarter expanded; 3 , half expanded; 4, three-quarters expanded; 5 , fully expanded. Every rooth section was examined. Pigment cells were examined in the centre and the extreme anterior and posterior levels of the eye in each section, and the position of the pigment processes was noted.

\section{RESULTS}

A dogfish eye, taken from an animal which had been in the dark, has a black ventral field and a black dorsal band. Much of the fundus, apart from the black areas, is cream-coloured, a rose-coloured band crosses the centre of the fundus, and the regions adjacent to the black areas show a blue-green tint. When an excised opened eye is exposed to light, the rose-colour soon fades and the back and sides of the eye become blue-green, except for the fixed ventral field and dorsal black band.

Apart from the fading of the rose tint across the central fundus, no difference was observed between the eyes of fish kept in the dark and in the light. The appearance, observed in sections, of pigment cells at comparable levels in the tapeta of fish kept in darkness and in light was the same. The typical pattern is shown in Table $\mathrm{I}$, from the eye of a dogfish kept in the light. For comparison, measurements are given for a fish kept in the dark for an equal period (Table 2). Strong light (sunlight) did not cause the light areas of the excised eye to darken. Prolonged exposure (up to 38 days) to ventral illumination produced no alteration in the configuration of light and dark areas in the dogfish eye.

The retina, dissected from the eye of a dark-adapted fish, showed a slight purple tint, owing to the presence of visual purple. In a dissected piece of retina, the coloration appeared greater in the region of the horizontal stripe than in the ventral field. On exposing the dissected retina to light the rose colour soon faded. The rods in the region of the horizontal stripe are about twice as long as elsewhere, and to this circumstance may be ascribed the deeper coloration observed there.

In the tapetal stripe, above the optic papilla, the tapetal plates are very long and extend towards the surface at very acute angles; the bases of the plates are nearly or virtually parallel with the base of the retina (Fig. I). In the anterior half of the fundus, the plates slope posteriorly; in the posterior half, 
TABLE 1. PIGMENT CELL PATTERN FROM FISH KEPT IN LIGHT

Fish kept in the light for $\mathrm{I} 8 \mathrm{~h}$ ( $\mathrm{I} 3 \mathrm{~h}$ in the dark followed by $\mathrm{I} 8 \mathrm{~h}$ in the light).

$\begin{array}{cccc}\begin{array}{c}\text { Level dorso- } \\ \text { ventrally } \\ \begin{array}{c}\text { Section } \\ \text { 100 }\end{array}\end{array} & \begin{array}{c}\text { Anterior } \\ \text { margin }\end{array} & \begin{array}{c}\text { Centre of } \\ \text { fundus }\end{array} & \begin{array}{c}\text { Posterior } \\ \text { margin }\end{array} \\ 200 & 5 & - & 4 \\ 300 & 4 & - & 4 \\ 400 & 4 & \text { I } & 3 \\ 500 & 2 & \text { I } & 3 \\ 600 & 2 & \text { I } & 3 \\ 700 & 2 & \text { I } & \text { I } \\ 800 & 2 & \text { I } & 2 \\ 900 & 4 & \text { I } & 3 \\ 950 & 4 & \text { I } & 3 \\ \text { optic nerve } & & & \\ \text { I000 } & 5 & \text { I } & 4 \\ \text { I100 } & 5 & 5 & 4 \\ & & & \end{array}$

TABLE 2. PIGMENT CELL PATTERN FROM FISH KEPT IN DARK Fish kept in the dark for $\mathrm{I} 3+\mathrm{I} 8 \mathrm{~h}$ (total of $3 \mathrm{I} \mathrm{h}$ in darkness).

$\begin{array}{cccc}\begin{array}{c}\text { Level dorso- } \\ \text { ventrally } \\ \begin{array}{c}\text { Section } \\ \text { 100 }\end{array}\end{array} & \begin{array}{l}\text { Anterior } \\ \text { margin }\end{array} & \begin{array}{c}\text { Centre of } \\ \text { fundus }\end{array} & \begin{array}{c}\text { Posterior } \\ \text { margin }\end{array} \\ 200 & 5 & 4 & 5 \\ 300 & 4 & \text { I } & 3 \\ 400 & 3 & \text { I } & 2 \\ 500 & \text { I } & \text { I } & 3 \\ 575 & \text { I } & \text { I } & 2 \\ 650 & \text { I } & \text { I } & 2 \\ 700 & 3 & \text { I } & 2 \\ \text { optic nerve } & 3 & 2 & 3 \\ 800 & 4 & 5 & 3 \\ 900 & 5 & 5 & 4 \\ \text { I000 } & 5 & 5 & 5\end{array}$



Fig. I. This and subsequent figures are of sections through the chorioid and contiguous retina of Scyliorhinus canicula. $\times 543$. Fundus, region of horizontal tapetal stripe, superior to optic papilla. Pigment cell processes wholly basal (index I). Longitudinal horizontal section. I, outer nuclear layer. 2, rods. 3, pigment epithelium (without pigment). 4, choriocapillaris. 5 , tapetal layer, 6, pigment cells with processes (layer of migratory cells). 7 , unmodified chorioid, containing static flat pigment cells. 8, scleral cartilage. 




Fig. 2. Longitudinal horizontal section, anterior region, superior to optic papilla. Processes of pigment cells partially extended (index 2). Numbering as in Fig. I.

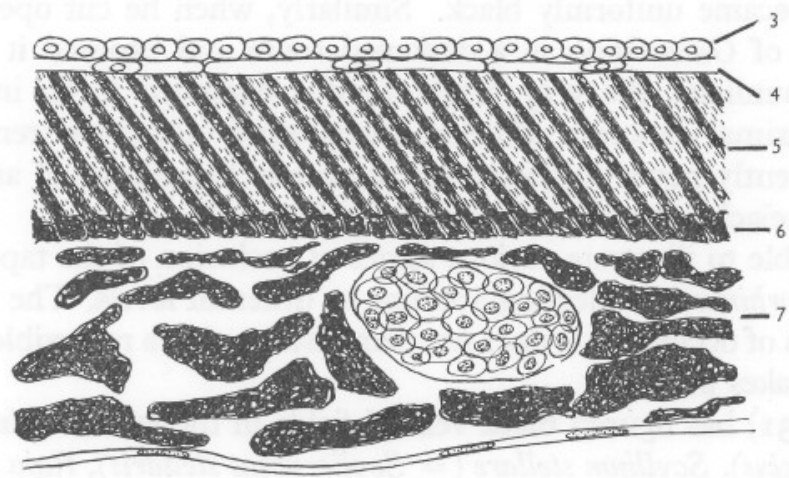

Fig. 3. Vertical transverse section through ventral field. Pigment processes extended (index 5). 
anteriorly. In anterior and posterior quadrants of the eye, the tapetal plates are short and are aligned almost vertically to the choriocapillaris. The degree of dispersion of black pigment along the tapetal plates varies with position (see Tables I and 2, Fig. 2). In the dorsal and ventral pigmented fields the processes of the pigment cells are fully extended and reach the outer surface of the tapetum (Fig. 3).

Sections from an eye fixed in ethanol were subjected to a few tests to characterize the pigments in the tapetal region. The reflecting pigment was not dissolved by water, ethanol and xylol; it was dissolved by acetic acid, 10\%; oxalic acid, $5 \%$; piperazine hydrate, $2 \%$; iron alum, $5 \%$; picric acid, saturated solution $(4 \mathrm{~h})$; sodium hydroxide, $2 \%$; ammonium hydroxide, I0 \%; hydrochloric acid, $2 \%$. In $5 \%$ ammonium hydroxide, the reflecting pigment was not dissolved in $30 \mathrm{~min}$, partially dissolved in $\mathrm{I} \mathrm{h}$, absent in $2 \mathrm{~h}$. These solubility characteristics are compatible with guanine. Histochemical tests for guanine are unsatisfactory and those tried were negative or ineffective, viz. murexide test, St Hilaire's test, ammoniacal silver nitrate.

The black material in the pigment cells of the tapetal layer was unaffected by all the reagents mentioned in the preceding paragraph, but was slowly bleached by $10 \%$ hydrogen peroxide. A melanin is indicated.

\section{DISCUSSION AND CONCLUSIONS}

Eyes of dogfish, Scyliorhinus canicula, have fixed, i.e. non-occlusible, tapeta. The triangular black field in the lower part of the eye is likewise permanent.

Franz, in his original accounts (1905, I913), described occlusion of the tapetum in only two species, namely Acanthia vulgaris (= Squalus acanthia) and Galeus canis (= Galeorhinus galeus); presumably, these were the only species in which he actually observed the phenomenon. He found that the background of the eye of Squalus, in darkness, was highly reflecting; but in sunlight it became uniformly black. Similarly, when he cut open the darkadapted eye of Galeorhinus in a darkened room and exposed it to artificial light or to sunlight, the very bright fundus darkened in an instant, soon reaching maximal darkness. Rochon-Duvigneaud (1943) has remarked that Franz apparently never subjected his ingenious hypothesis of an occlusible tapetum in selachians to experimental proof.

It is possible to illustrate various stages of occlusion of the tapetum in the eye of Scyliorhinus by selecting sections at different levels. The result indicates degrees of occlusion; it does not demonstrate that a reversible movement of pigment takes place.

Franz (I93I) has figured black ventral fields in the eyes of Mustelus laevis (= M. mustelus), Scyllium stellare (= Scyliorhinus stellaris), Raja clavata and R. batis.

A permanent black ventral field and reflecting fundus may, perhaps, be 
features concerned with visual acuity and sensitivity. The ventral field receives maximal illumination from above; the reflecting fundus, from lower levels and from the bottom, where illumination is less. Visual acuity is probably better on a black non-reflecting surface and sensitivity is enhanced by a reflecting tapetum. The dogfish Scyliorhinus canicula is nocturnal and lives on the bottom; the organisation of its tapetum appears to be related to its habits. A further study is now being undertaken of tapeta in other elasmobranchs, with a view to relating them to the habits of each species.

\section{SUMMARY}

Tapeta were examined of light- and dark-adapted dogfish, Scyliorhinus canicula. The tapetum in the eye of this fish is fixed; pigment processes in the tapetum do not move when a fish is changed from dark to light and vice versa. A black ventral field and a bright dorsal fundus are always present.

\section{REFERENCES}

FranZ, V., 1905. Zur Anatomie, Histologie und funktionellen Gestaltung des Selachierauges. Fena. Z. Naturwiss., Bd., 40, pp. 697-840.

- I913. Sehorgan. In: Lehrbuch der verleichenden mikroskopischen Anatomie der Wirbeltiere (ed. A. Oppel), Teil 7, 4I7 pp. (Chorioidea, Selachier, pp. I66-9). Jena: Fischer.

— I93I. Die Akkommodation des Selachieruages und seine Abblendungsapparate, nebst Befunden an der Retina. Zool. Fahrb., Abt. allg. Zool. Physiol. Tiere, Bd. I9, pp. 323-462.

- I934. Vergleichende Anatomie des Wirbeltierauges. In: Handbuch der vergleichende Anatomie der Wirbeltiere (ed. L. Bolk, E. Göppert, E. Kallius and W. Lubosch), Bd. 2, 2 Hälfte (Plagiostomen), pp. 1009-23. Berlin and Vienna: Urban and Schwarzenberg.

Nicol, J. A. C., 1960. The Biology of Marine Animals. London: Pitman.

Rochon-Duvigneaud, A., 1943. Les yeux et la vision des Vertébrés. 719 pp. Paris: Masson.

— 1958. L'oeil et la vision. In: Traité de Zoologie, ed. P.-P. Grassé. T. I3, Fasc. 2, pp. I099-IIIO. Paris: Masson.

Walls, G. L., I942. The Vertebrate Eye and its Adaptive Radiation. 785 pp. Bull. No. 19, Cranbrook Inst. Sci., Bloomfield Hills, Michigan. 